\title{
HISTORY OF CHICAGO
}

PEARL BACKUS CARLEY

Third Grade, Francis W. Parker School

The children of the third grade have studied the history of the growth of Chicago from the time it was a mere trading-post and fort, environed by swamps, through its pioneer stage; and through their own struggles with some of the problems of these early settlers, they have come to a genuine, though childish realization of some of the most obvious of the present needs of the city.

The work will appear in The Elementary School Teacher in two sections; the first being "Chicago of Long Ago," and the second, "Some of the Past and Present Problems of ChicagoTransportation, Water Supply, and Drainage."

To present the work adequately it would be necessary to give much of the correlated work in geography, industrial science, mathematics, handwork, and art. It would be essential to give the reading-slips that have been specially adapted from reliable sources and printed for the use of the children. However, one child's work in the subject makes a book of about I 50 pages. We are therefore forced, in reducing this material to the limit of two articles, to select from among the papers written by the children only those most essential in telling a brief story of Chicago's growth through the past century.

The motive of making a book of the history of Chicago which is to be both complete and beautiful appeals very strongly to the children of the third grade. Its tendency is to bring about the maximum of good careful work, and to reduce the amount of drill necessary to secure accurate formal work to the minimum. The second great incentive to careful work in expression has been the pictures with which the books are illustrated. Each child has nearly 50 pictures (obtained by teacher and reduced to proper size) from histories, books in the public library, pictures in buildings, and from historical landmarks, such as tablets and statues. 
The index given below will give some idea of the contents of each child's book :

\section{PART I}

How Chicago Looked a Hundred Years Ago

Swamps in Chicago

Some of the Birds Found in Swamps

Red-winged Blackbird

Yellow-headed Blackbird

The King-fisher

The Snipe

The Turnstone

The Little Green Heron

The Great Blue Heron

Sora Rail

Wild Geese

Wood Duck

Woodcock

Stories of Indians

Indians' Dress

Indian Homes

Wigwam

Summer Home

Winter Home

Indian Village

How the Indians Travel

How They Cook Their Food

How They Light Their Fires

How They Gather Wild Rice

How They Hunt and Fish

Elk Hunting

Buffalo Hunting

Hunting Buffalo.with Decoys

Antelope Hunting

Hunting Deer with Decoys

Hunting Bears

Hunting on Snowshoes

Story of Beavers

Trapping Animals

Fishing

Fishing with Bow and Arrow

Fishing with Soap Root

Picture-writing

Building Canoes

Indians in Lincoln Park

This content downloaded from 096.084.152.241 on February 21, 2018 15:50:29 PM All use subject to University of Chicago Press Terms and Conditions (http://www.journals.uchicago.edu/t-and- 
Building Fort Dearborn

Plan of Fort Dearborn

Mr. Kinzie Comes to Chicago

The Kinzie Mansion

Fur-trading

How Chicago Looked in I8I2

Tecumseh

Revolutionary War

War of 1812

First Indian Trouble

Massacre of Fort Dearborn

Black Partridge

Captain William Wayne Wells

Fort Dearborn Statue

PART II

After the War of 1812

Fort Dearborn Rebuilt

Government Bought Land for Canal

Coming of Settlers

How They Traveled

Traveling in Flat Boats

Traveling in Prairie Schooners

Traveling in Sledges

Traveling in Ox Carts

Traveling on Pack Horses

Mr. and Mrs. Kinzie's Traveling Experiences

How Chicago Looked in I83I

Making Dip Candles

Making Candles with Molds

Making Gas

How Gas Is Collected

How Gas Is Made on a Large Scale

Old-fashioned Flint and Steel

Old-fashioned Fire Place

River Water

Sweep Wells

Selling Water from a Cart

Water System-Log Pipes-Pier I50 Feet Long

First City Water Works

Second City Water Works

The Tunnel

The Crib

The Drainage Canal

Plan for North Shore Sewers

This content downloaded from 096.084.152.241 on February 21, 2018 15:50:29 PM All use subject to University of Chicago Press Terms and Conditions (http://www.journals.uchicago.edu/t-and- 
How the River Used to Bend

Chicago Harbor

Lifting Chicago Out of the Mud

Intersecting Sewers

The Train of Cars

The F. W. P. Fast Freight

\section{CHICAGO OF LONG AGO}

\section{PART I}

HOW CHICAGO LOOKED A HUNDRED YEARS AGO

Long ago there were Indians all around Chicago. The only house was a $\log$ cabin on the north side of the river. There were swamps all around. In the swamps there were snipe, heron, wild geese and wild ducks. There were many wigwams on the south side of the river. In the log cabin there lived a Cuban, whose name was Mr. Au Sable. Mr. Au Sable came to Chicago to try to be an Indian chief, but the Indians would not have him, so he sold the cabin to Mr. LeMai. He came to trade with the Indians. Then he sold it to Mr. John Kinzie, who stayed here as long as he lived. In the tall grass there were prairie chickens, and further out on the prairies there were buffaloes. In the woods were bear, foxes, and wolves. There were deer in the woods too. There were no street lamps to be seen, no houses nor cars. The squirrels frisked in the trees. There were beautiful flowers in swamps and along the banks of the river. EleANor Holbrook

\section{SWAMPS}

If you had been in Chicago years ago you would have seen many swamps on the South Side. A man lived here in 1830 and wrote to his friend telling him how the hunting was, and this is a portion of the letter: "Vast quantities of water fowl were feeding on the wild rice, seeds, and insects in the swamps. . . . Swan, geese, and brant, passing to and fro in clouds, keep up an incessant cackling. .... There were ducks of every kind, from the mallard and canvasback down to the tiny water-witch and blue-winged teelwhile hundreds of gulls hovered gracefully over the swamp."

\section{LUDWELL LINCOLN}

We have not all visited the swamps but some of us have seen swamps. We had a number of pictures and slides of swamps. This is the way the swamp looked to us. The tall reeds, rushes, cat-tails, wild rice, and water lilies grew in them. You will find dragon-flies and fish and frogs there too. The yellow-headed blackbird and red-winged blackbird are swamp birds. They feed on the wild rice. 


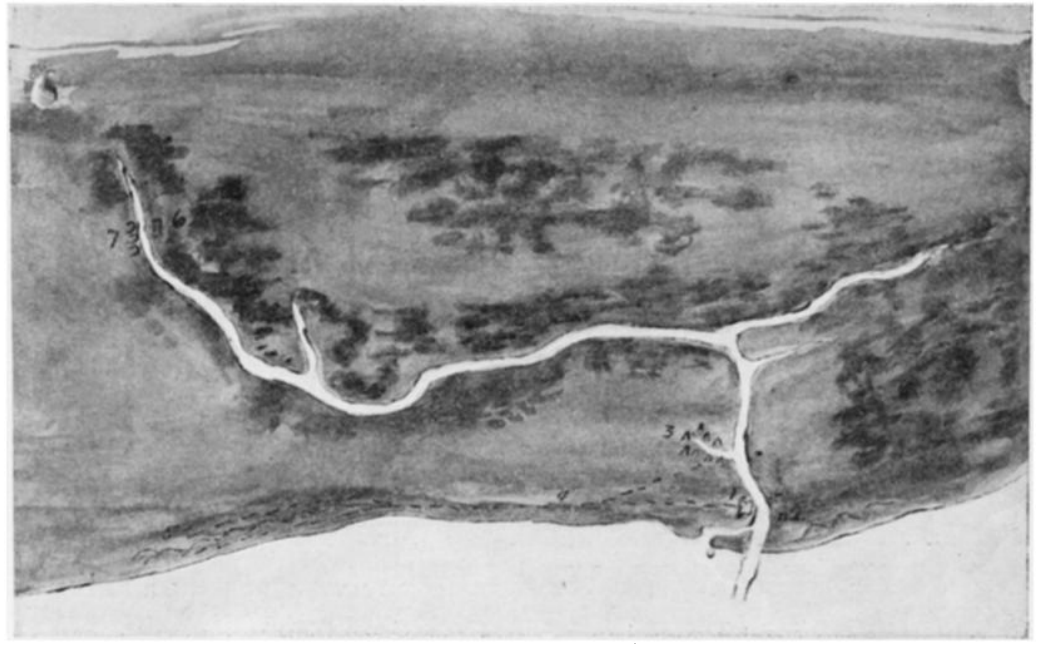

r. Fort Dearborn.-2. Kinzie House.-3. Indian Encampment.-4. Indian Trail.-5. Sand Hills-Battle Ground, 1812.-6. Lee's Cabin.-7. Hay Stacks.

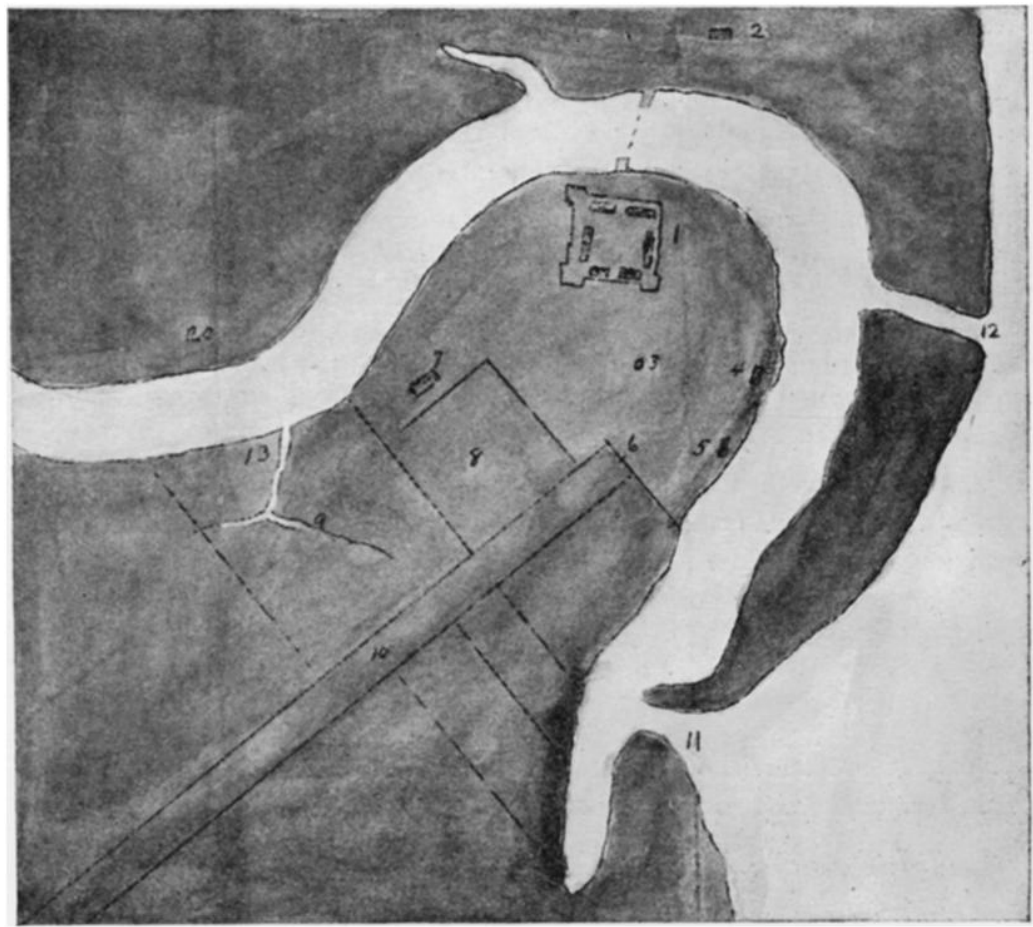

I. Fort.-2. Kinzie House.-3. Well.-4. Wash House.-5. Shop.-6. Gate.7. Barn.-8. Garden.-9. Cultivated Field.-ro. Road - Ir. Old mouth of river. -12. Channel cut in 1828.-13. Creek-where State Street is now.

This content downloaded from 096.084.152.241 on February 21, 2018 15:50:29 PM All use subject to University of Chicago Press Terms and Conditions (http://www.journals.uchicago.edu/t-and- 


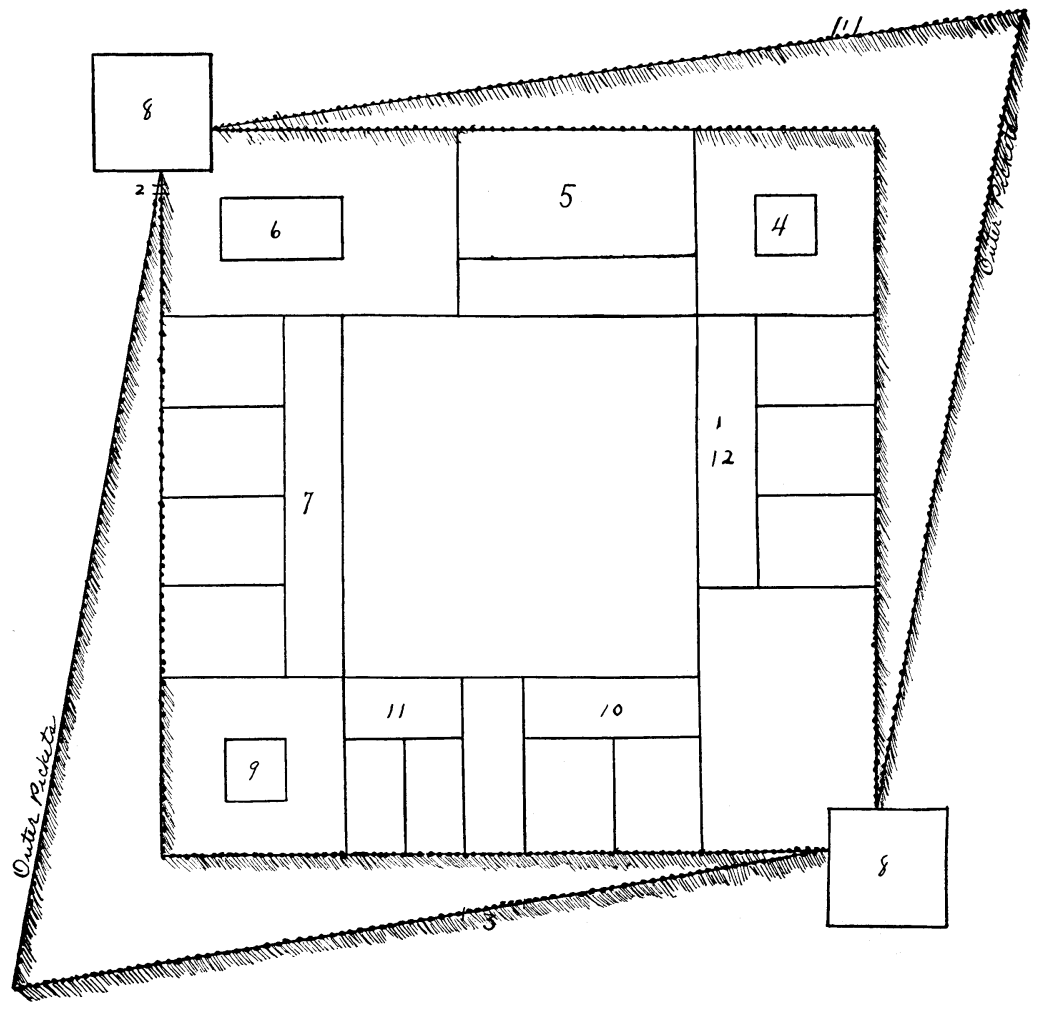

Plan of Fort Dearborn

I. Tunnel and Underground Well.-2. Wicket Gate.-3. Main Gate.-4. Store House.-5. Contractor's Store.-6. Magazine.-7. Officers' Barracks.-8. Block Houses. 9. Stone House.-Io. Soldiers' Barracks.—II. First Floor-Guard House. Second Floor-Hospital Store.-I2. Commisary Officers' Barracks.

You would find the turnstone on the shore, turning stones over to get the insects under them. His bill is turned up a little bit, so he can turn the stones over.

Matilda Delano

The little green heron goes far out into the swamp to get his food. The great blue heron gets his food in the same way, only he wades out a little farther.

They walk out very slowly, and when they see a fish or frog come up above the surface they stick their long bill after it. We saw the great blue heron in Lincoln Park.

Geneva Harrison

The snipe has very large toes. They act like snowshoes, so that he can walk in marshy places without sinking. He likes to go into marshy places and put his bill in the mud and get worms. The snipe's bill is moveable at the end, and he has his eyes near the back of his head so when he is 
digging he can see a hunter come. The snipe is a good game bird, but he is very hard to catch.

The woodcock is very much like the snipe in habits. He likes to stay in marshy places too, and eat earthworms. The woodcock is disappearing very fast, because the laws do not protect him. He goes south in winter. Down in Texas they have a law that no game birds can be shipped out of the State. The time they are killed is mostly in the spring when they are nesting. They kill the old birds and the little ones are not strong enough to take care of themselves.

HELEN BRECKER

Wild rice grew on the banks of the Chicago River. The Indian squaws would go out and gather it long ago. They would paddle along in their

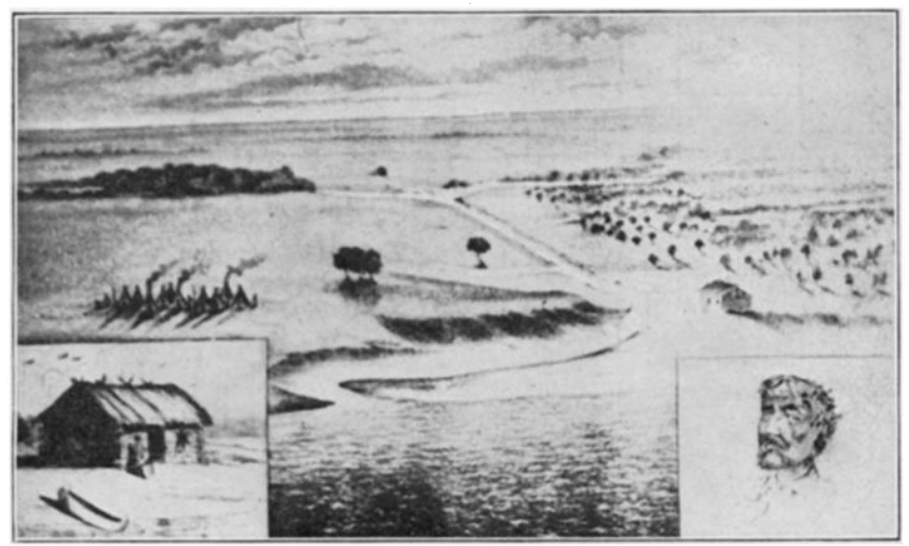

Chicago a Hundred Years Ago

canoes. When they came to a big patch they would bend the rice stalks over their canoes and beat them. They had a big mat in the bottom. They would empty the rice into a big basket. They gathered until their baskets were filled. They used the rice for food.

ENID WingerT

\section{HUNTING}

The life and comfort of the Indian depended upon his skill and success in hunting. They needed the skins for clothing, for the wigwams, and the meat for food. The Indians had to learn the habits of the animals in order to catch them.

FOWLER MCCORMICK

\section{BUFFALO HUNTING}

When the Indians go to hunt Buffalo the whole village goes-the squaws, papooses, and all the children. They like to watch the hunt, and they are afraid to stay home. They climb a tree or hide behind the bushes. When they see the herd they give the signal.

Frieda Maynard 


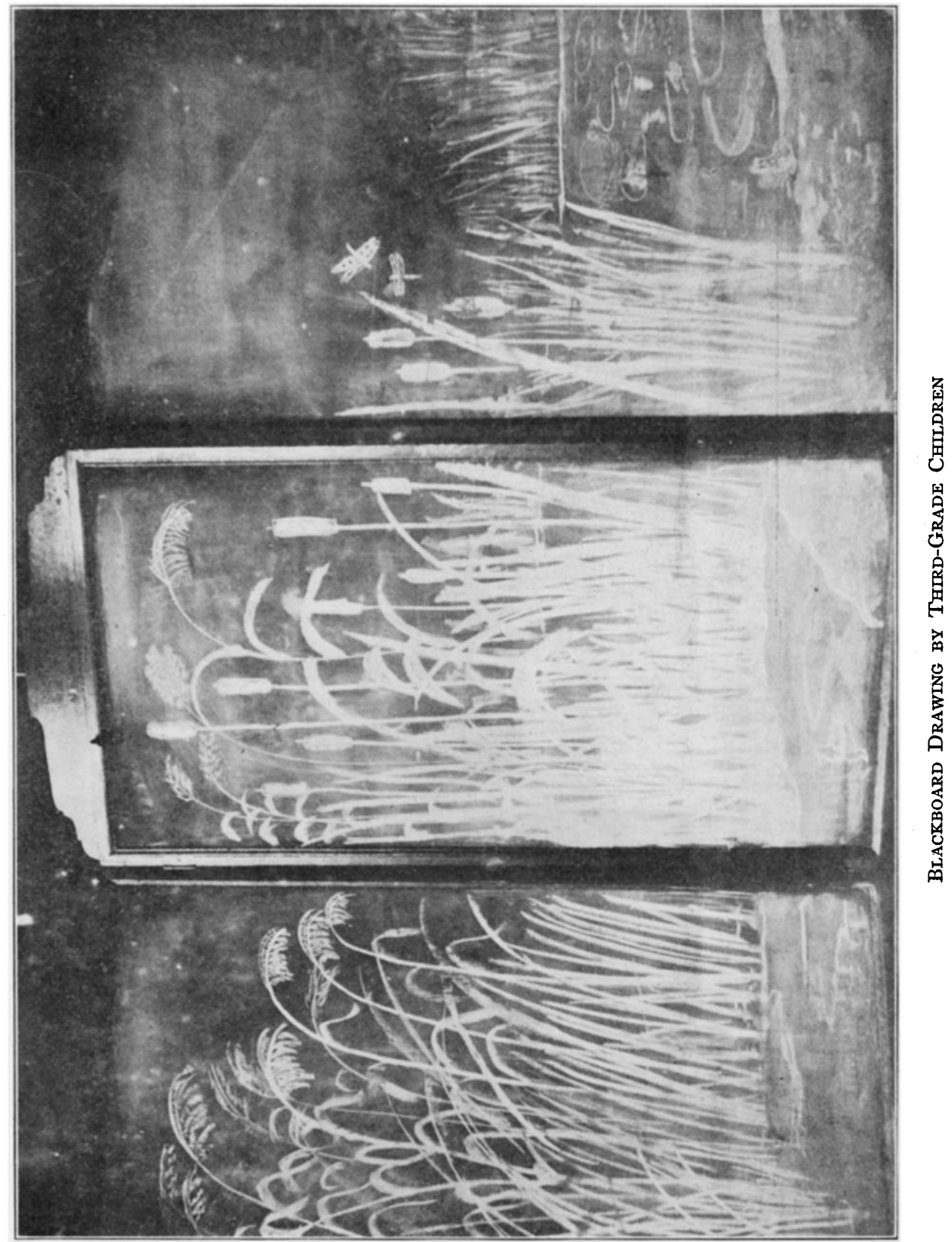

This content downloaded from 096.084.152.241 on February 21, 2018 15:50:29 PM All use subject to University of Chicago Press Terms and Conditions (http://www.journals.uchicago.edu/t-and- 
The Indians sometimes hunt the buffalo with decoys. When the Indians hunt with decoys they cover themselves with wolf skins. A herd of buffalo

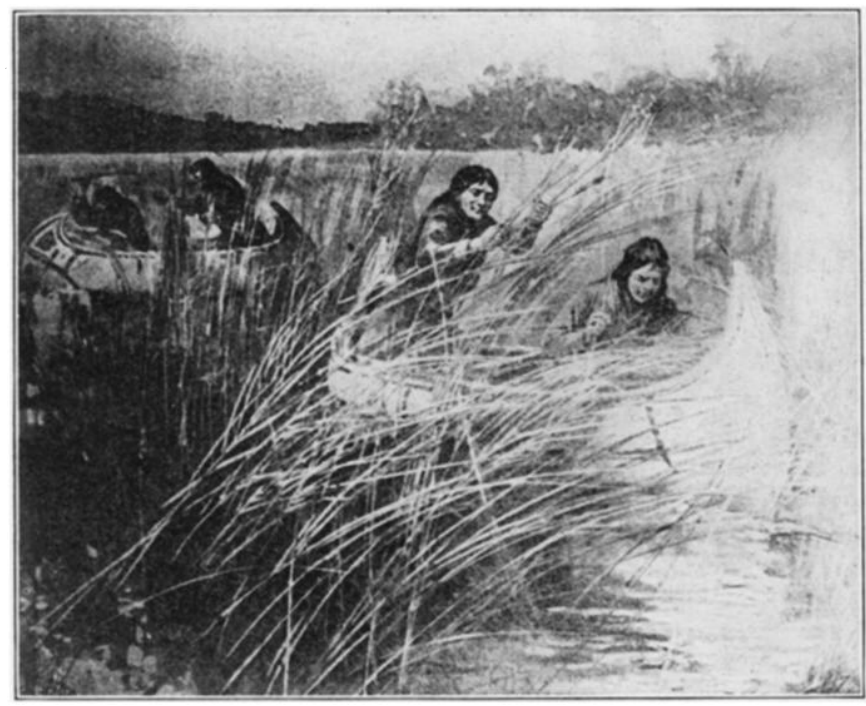

WILD RICE

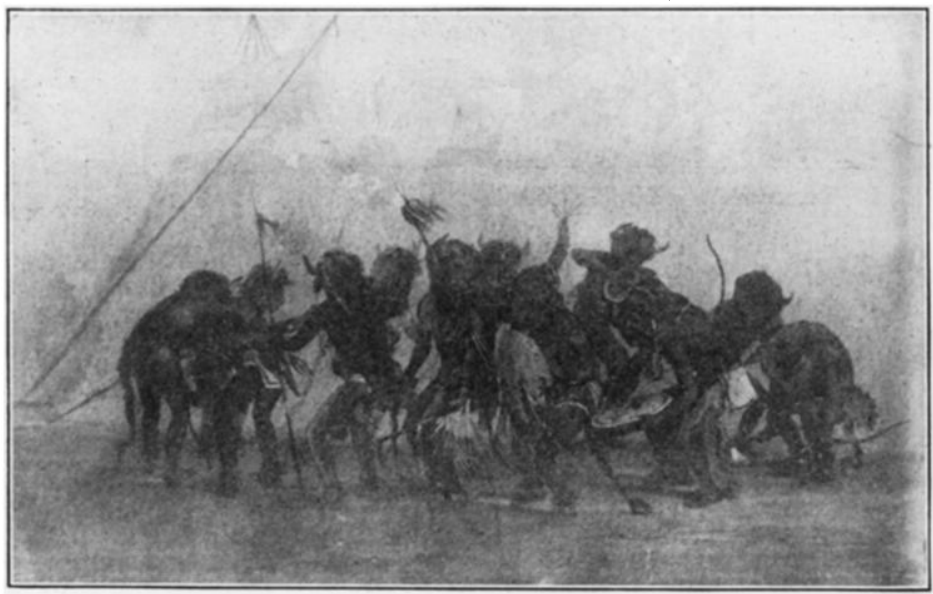

\section{Buffalo Dance}

is not afraid of one or two wolves. Then the Indians creep up near enough and use their bows and arrows.

This content downloaded from 096.084.152.241 on February 21, 2018 15:50:29 PM All use subject to University of Chicago Press Terms and Conditions (http://www.journals.uchicago.edu/t-and- 
ANTELOPE HUNTING

The Indians have to study the different habits of the animals. This is one of the ways the Indians hunt antelope. They put a stick with a piece

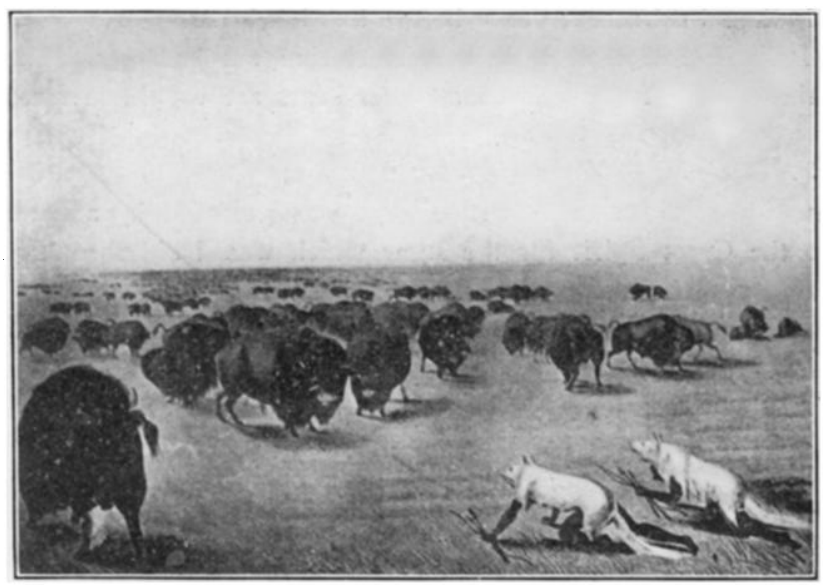

Hunting Buffalo with Decoys

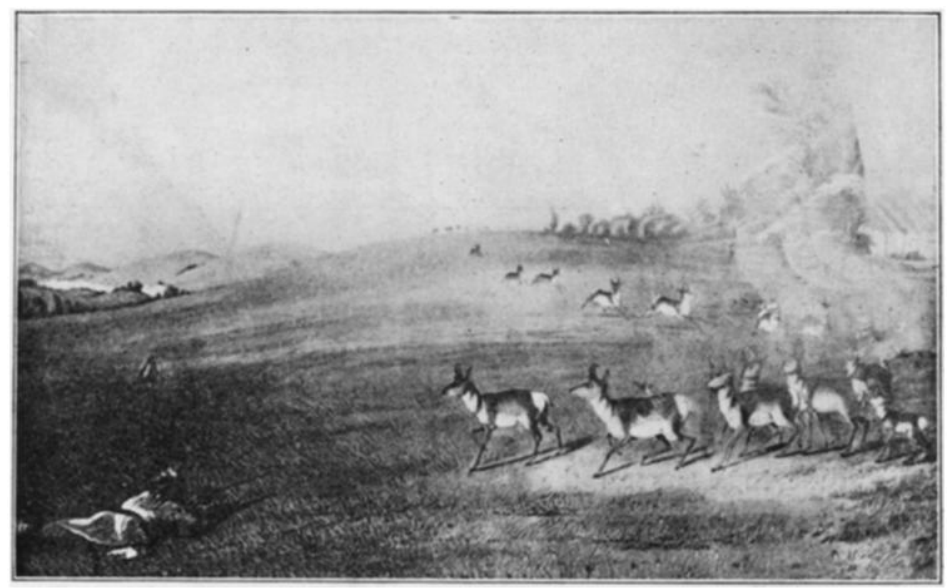

of something that is red on it. They lower and raise it. They did this because they found that the antelope were very inquisitive and would come very near. The Indian would be hiding in the tall grass and would shoot with his bow and arrow.

Matilda Delano

\section{DEER HUNTING}

The Indians sometimes hunted deer at night in canoes. They would put a piece of birch bark in front of the canoe and sit behind the bark. They 
would hold a torch in front and it would blind the deer. Then they would paddle nearer and the deer was not able to get away because the light confused it.

Hildegarde Pabst

HUNTING BEARS

The Indians held a bear dance before hunting bears.

The Indians worry the bears and tire them out before attacking them, because they are so ferocious. Sometimes bears are caught in traps.

RUth COOPER

SNOWSHOE HUNTING

In snowshoe regions a snowshoe hunt was preceded by a dance giving thanks to the Great Spirit for the snow which would aid them in bringing

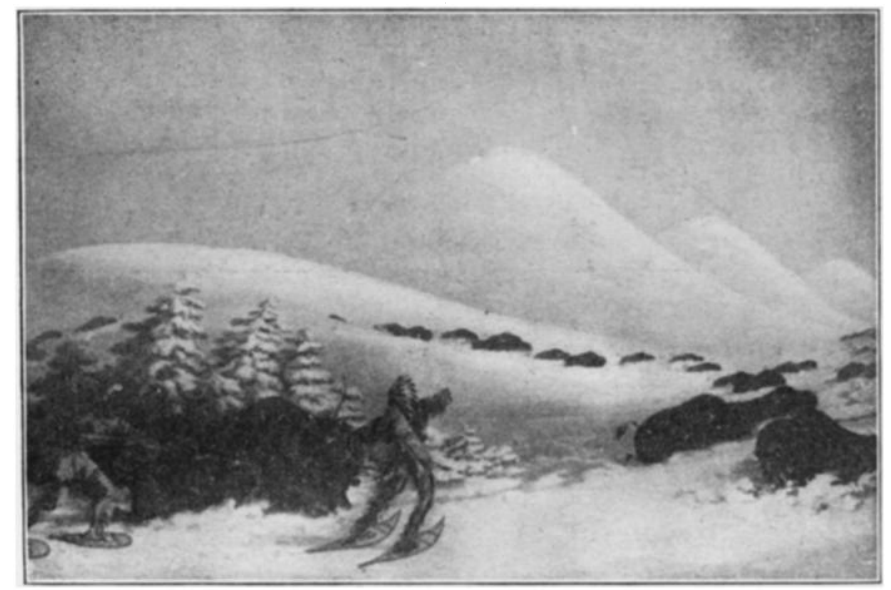

Hunting Buffalo on Snowshoes

home their game. Snowshoes serve well in hunting moose and buffalo, as they could be easily surrounded or overtaken in the deep snow.

VINCENT Fischer

FISHING WITH BOW AND ARROW

Usually the Indians spear the fish, but sometimes they shoot the sunfish with bow and arrow. There is a little string tied to the bow and arrow, so when the arrow goes into the water the fish will not take it away.

PAUL TABER

\section{FISHING}

They take a long pole, with barbs in the end of the pole, and put attractive bait on the barbs. They twirl the pole. That attracts the fish. It catches them on the barbs.

ArNold Horween

The soap root was used at a low stage of water, late in summer. Indians dug the root and pounded it. This was rubbed by handfuls on rocks in streams. This roiled the water and made it somewhat foamy. Fish 
were affected by it. They became stupid and came to the surface. The Indians used scoop baskets to catch them.

HeLEN BRECKer

\section{PICTURE-WRITING}

I am going to tell you how the Indians write. They don't write. They make pictures instead of writing as we do. They write on skins-sometimes on deer skins, sometimes on buffalo skins, and sometimes on birch bark. When they want to remember anything they paint it, and that is the way they do.

ENID WINGERT

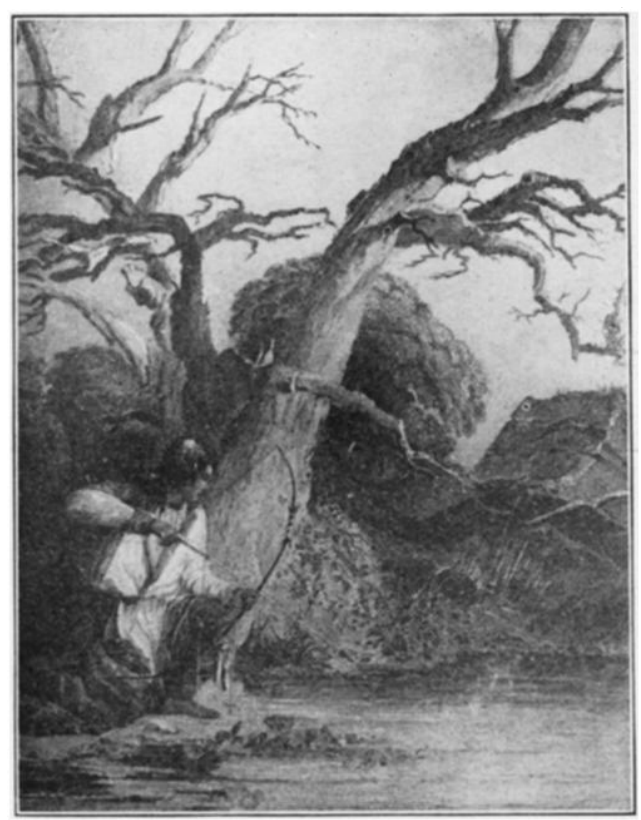

FIsHing with Bow AND ARRow

THE INDIANS IN LINCOLN PARK

The Indians came to Lincoln Park on Chicago's birthday, October, 1905. A hundred years ago the Indians' grandparents lived here. This is a picture of an Indian wigwam that was in Lincoln Park. ANNA WreboLdT

FORT DEARBORN

Fort Dearborn was built for the people and to protect the traders. The fort was built on the highest part of the river where it turned south. The government saw that they needed a fort, so they sent Captain Whistler to Chicago to build it. Captain Whistler came in a schooner and the soldiers came on foot. Captain Whistler got along very well until he came to the mouth of the river. It became so shallow there that they could see the sand 
at the bottom. He could not get his boat through, so he had to unload. Some Indians wete standing on the shore and saw the schooner. One
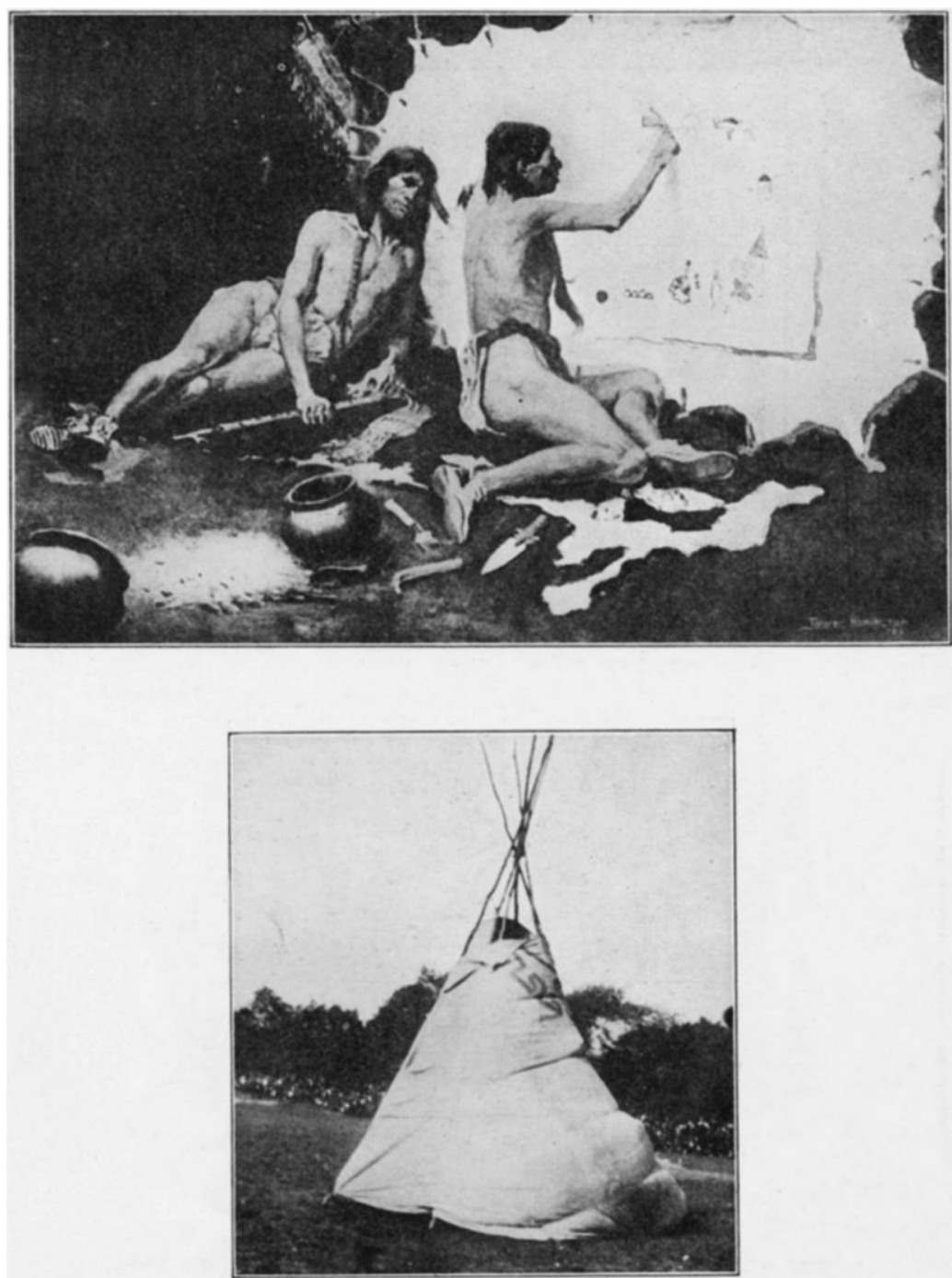

INDIAN Wigwam in Lincoln Park

Indian said "Great bird." Another Indian chief said, "Canoe with wings." Captain Whistler's soldiers came to Chicago safely. It was very hard to build a fort.

Elizabeth Beck

This content downloaded from 096.084.152.241 on February 21, 2018 15:50:29 PM All use subject to University of Chicago Press Terms and Conditions (http://www.journals.uchicago.edu/t-and- 
THE KINZIE HOME

Mr. Kinzie sent to Canada for some lumber. He enlarged his house by building rooms at the side. He made a garden around it. Then he planted Lombardy poplars in front of it. When Mr. Kinzie's house was finished it

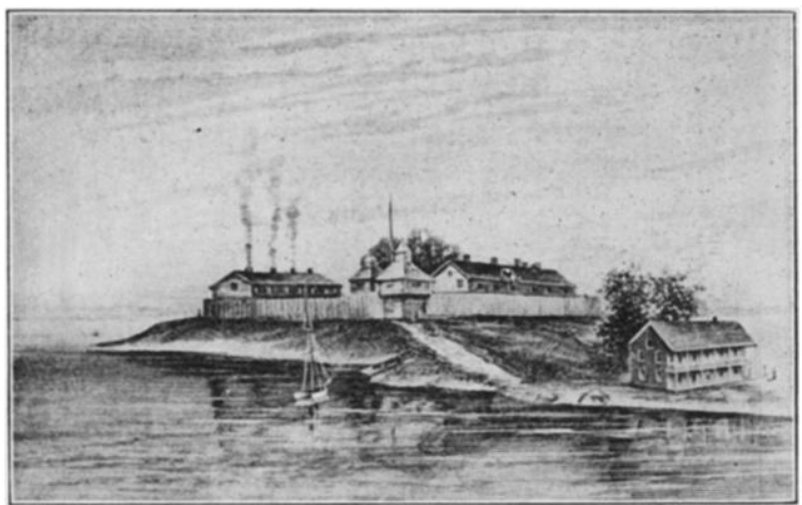

FORT DEARBORN

was so snug and cozy that the other settlers called it the Kinzie mansion. The Indians were very friendly. They never knocked at the door. They would walk in and say "How, how." That meant hello. Then they would

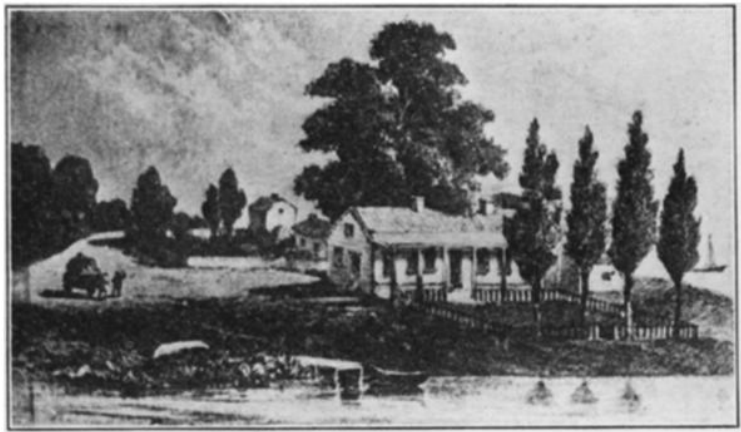

The Kinzie House

sit down and tell the children stories. Mr. Kinzie played the fiddle and the Indians liked to watch the children dance.

MARguerite DoepfNer

FUR-TRADING

When Fort Dearborn was built Mr. Kenzie built a trading post. At the trading post many Indians came to trade and many canoes dotted the river. The cabin in which the trading was carried on stood on the north side of the 
river and was built behind the cabin of Mr. Kinzie. The Indians in exchange for the furs got guns, kettles, hatchets, blankets, and sometimes ammunition. Some Indians came down the Mississippi River, up the Illinois, through the Des Plaines, across the Chicago portage to the Chicago river. Mr. Kinzie

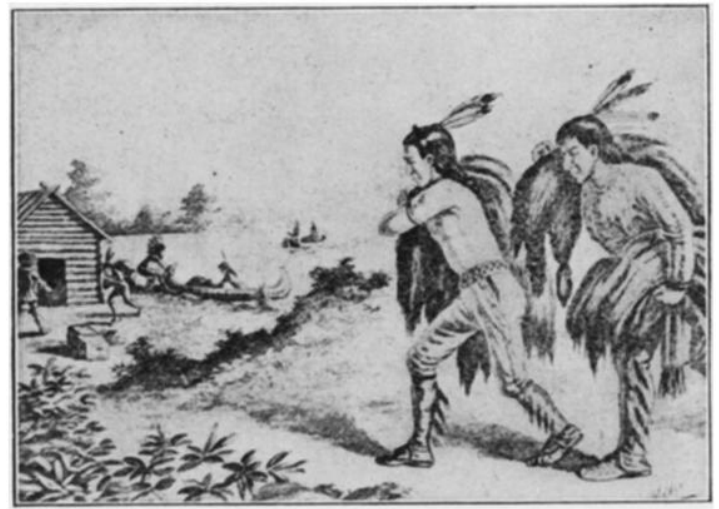

INDIAN FUR-TRADING

had the Indians get furs for him because they cculd capture the animals more easily. They brought otter, mink, beaver, bear, martin, wolf, fox, wild-

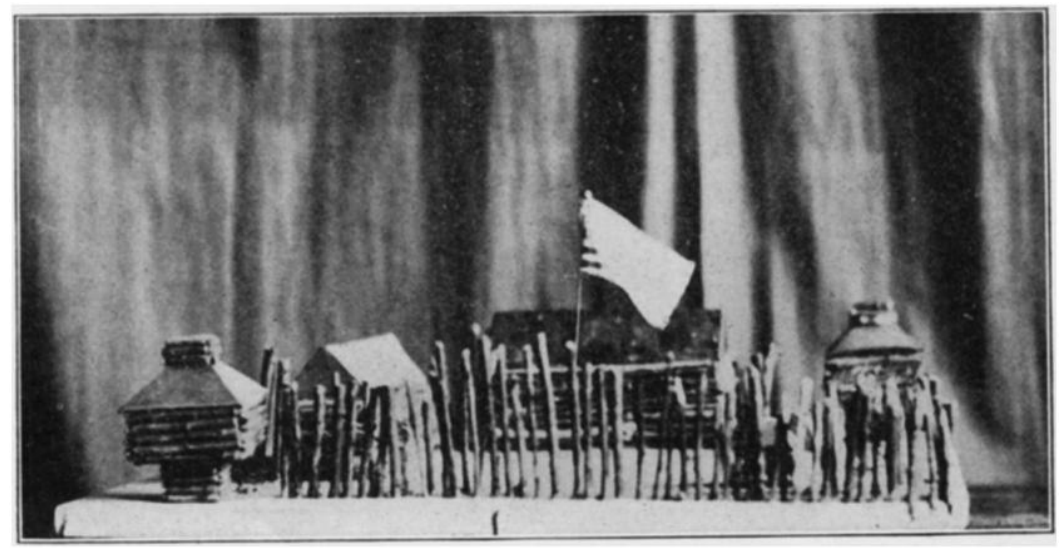

Model of Fort Dearborn Made by Third-Grade Children

cat and deer. The squaws sometimes brought little birch-bark boxes and canoes filled with maple sugar, because they wanted to get ribbons, beads, and looking-glasses.

HiLdegarde Pabst 
THE REVOLUTIONARY WAR

The Revolutionary War was a war we had with England to free ourselves from them. The war of 1812 was another war we had with England. That was at the same time we had trouble with the Indians in Chicago.

In I8I2 the Indians felt very brave, and they looked in at the fort and said, "The white squaws will not be so glad in a little while." The reason that the Indians felt so brave was because the English were against the people in Chicago.

Helen Stauffer

[To be continued] 